\title{
DUBROVNIK BY TADIJANOVIĆ - A SPACE OF INTIMATE IN THE SERVICE OF THE ETERNAL
}

\author{
Tonći Lazibat
}

\begin{abstract}
From the very beginnings of its founding, the city has had a great significance: started as the center of social life, in a diachronic sense it has become a place of gathering of different centers of power, the public space, as well as the space of the private - by weaving collective and individual memory into it. The latter is recognized in Tadijanovićs Poems of Dubrovnik, a collection of fourteen poems for which the poet finds inspiration in the Town of Poets, over and over again, during the seventyyears time span. It is the city he loved from the very first moment, but in which he was loved as well, thus he often comes back in his thoughts, linking past, present and future. We have highlighted the four phases of his writing inspired by the Eternal City and have related the theme-motive background with the poet's age. It is noticed that, in relation to the youthful and playful first love, the worries, the enthusiasm and the exhilaration, his later lyric is pervaded by philosophical concerns about the meaning of life, death, transience and the life's drab, but he does not therefor diminish the importance of Dubrovnik. With his first and last poem he creates a kind of alpha and omega of his Dubrovnik opus, signifying Dubrovnik as one perfectly finished mindset, by its cyclical reminding on the circle and thus on the reproducibility of the life cycle: birth - life - death - rebirth (through re-readings of poems, in the poet's case).

Keywords: city, Dragutin Tadijanović, Dubrovnik, Poems of Dubrovnik, Poetry
\end{abstract}




\section{Introduction}

In the history of the human race the city has always been of a great significance. From ancient Greece and Rome, its central space (agora or forum) has been an important social center (Mumford, 1968), and besides this socialization role its importance is in the urbanism. The relation towards the urban extends from excitement to alienation, from urbanophilia to urbanophobia (Nemec, 2010). For Barthes (1989), in the western sense, the city is the foundation of all civilizational values such as spirituality, power, money, clothing, and word. However, the city is not only a public space, but also an intimate one.

The importance of the city has also been recognized by a poet Dragutin Tadijanović during his hundred years long life and more than eighty years long creativity ${ }^{[1]}$. Although literary historians and literary critics often record his preoccupation with the native village of Rastušje being brought into a contrasting relationship with Slavonski Brod, there are a number of cities in his poems, one of them being Dubrovnik.

Numerous research, analyzes, referrals and lectures on scientific and professional meetings have been held about this poet and his work. However, the number of those discussing his relationship with Dubrovnik has been insignificant.

At the last international scientific meeting on Tadijanović in 2017, entitled Tadija's century: history, culture, identity, two lectures focused on the poet 's link to Dubrovnik. Thus, Katja Bakija talks about Dubrovnik in the poetry of Dragutin Tadijanović, and the duo Marija Benić Penava and Daniel Dujmić about the Poet and the City 1923. Since there are no

[1] Literature historians note that Dragutin Tadijanović (1905 - 2007) was born in Rastušje (Frangeš, 1987: 529; Jelčić, 2004: 410; Prosperov Novak, 2003: 354). After attending an elementary folk hool in Podvinje, he was a student of real gymnasium in Slavonski Brod by the age of 20. Although in 1925 he enrolled for a Forestry Study in Zagreb, after three years he became a student of the history of South Slavic literature and philosophy at the Faculty of Philosophy in the same town (Frangeš, 1987: 529). In addition to the initially predominant preoccupation with the native village, in his poetry Tadijanović speaks about the city. Speaking of Tadijanović's urban themes as primarily young men lost in the meanders of the modern city, the contrast between the asphalt surface and the endless Slavonian fields, and the conflict between the natural and the reprehensible, Frangeš removes the poet of the village stigma and calls him a predominantly urban poet." (Frangeš, 1987: 342). In his poetry, Jelčić recognizes Tadijanović's "experience of the city that has created an essential antithesis of his poetry", that is, "Rastušje is not just a contrast to the city but the constant which is in his poem implied as a measure of life, its values and beauty" (Jelčić 2004: 411). Though these two literary historians link the poet and the sense of being lost in the city, the third historian Prosper Novak claims that Tadijanović "was happy his entire life that in the big city he had a chance to take part in the spell of language and that he managed this difficult alchemical process, this spell of language and its symbolism, with ease" (Prosperov Novak, 2003: 354). 
written records of these lectures, it is difficult to discuss the authors' comprehension and how much it would overlap with ours. However, the aforementioned duo consists of a historian and a doctoral student of postgraduate scientific studies not linked to literature, so the conclusion is that they do not observe the poet's relationship from a literary standpoint.

This lack of newer consideration of the relationship between the poet and Dubrovnik and the obsolescence of some older works, has prompted us to re-read, interpret and analyze his poetry collection Poems of Dubrovnik. Although most of the work on Dragutin Tadijanović has been referring to the fact that he was not comfortable in the city and was constantly bringing it in contrast to his Rastušje, we assume that this does not apply to Dubrovnik. In other words, poems in which he is unhappy because of his stay in Slavonski Brod are the result of a very young poet who left the security of his family home for, in his eyes, a big city. We think this bad experience of a city is conditioned by a sudden change for such a young person and that the years of life experience have later contributed to his different relationship with any other city, including Dubrovnik.

\section{Methodology}

The hypothesis of this work is that the poet, in spite of being labeled as the one who have always preferred the village over the city, liked to stay in the city of Dubrovnik. In order to confirm or reject this hypothesis, we must achieve the following goals: (1) Determine in which life periods Tadijanović used to write about Dubrovnik, and (2) abstract the themes and motives of his fourteen poems from the Poems of Dubrovnik. Finally, the poet's age would be correlated with this topics and motives.

We will use the inductive and deductive method, compilation method, comparator method, analytical and synthesis methods and table descriptions to generate a paper as systematic as possible. 


\section{Interpretation and analysis of results}

The poet 's collection Poems of Dubrovnik, released in 2003, consists of three parts: fourteen poems by Tadijanović, followed by his comments on the three poems, and four poems by Luko Paljetak dedicated to Dragutin Tadijanović. For the analysis of this collection, we will only use the body of 14 mentioned poems in total, according to Table 1 which presents the title of each poem and the place and year of its origin respectively (regardless the poet's frequent full date information).

Table 1. Tadijanović's poems from the Poems of Dubrovnik

\begin{tabular}{|c|l|c|c|}
\hline No. & \multicolumn{1}{|c|}{ Poem's title } & Place of origin & $\begin{array}{c}\text { Year of } \\
\text { origin }\end{array}$ \\
\hline 1 & A thought about you & $\begin{array}{c}\text { (Slavonski) } \\
\text { Brod }\end{array}$ & 1923 \\
\hline 2 & $\begin{array}{l}\text { The old olive groves dreaming their } \\
\text { dreams }\end{array}$ & $\begin{array}{c}\text { (Slavonski) } \\
\text { Brod }\end{array}$ & 1923 \\
\hline 3 & A devotee by the blue sea & $\begin{array}{c}\text { (Slavonski) } \\
\text { Brod }\end{array}$ & 1923 \\
\hline 4 & Epistle & Zagreb & 1951 \\
\hline 5 & My Dubrovnik & Dubrovnik & 1953 \\
\hline 6 & Majesty of the sea & Dubrovnik & 1954 \\
\hline 7 & Recorded in the cemetery & Lapad & 1959 \\
\hline 8 & To you for a birthday & Dubrovnik & 1959 \\
\hline 9 & Only a wish & Dubrovnik & 1959 \\
\hline 10 & Confusion & Dubrovnik & 1959 \\
\hline 11 & $\begin{array}{l}\text { About oblivion, about words, about } \\
\text { wind }\end{array}$ & Dubrovnik & 1961 \\
\hline 12 & $\begin{array}{l}\text { Rhymes about a dog on the } \\
\text { cemetery gate }\end{array}$ & Dubrovnik & 1962 \\
\hline 13 & Servant to the words & Dubrovnik & 1974 \\
\hline 14 & A poem to St. Blaise in Dubrovnik & Dubrovnik & 1995 \\
\hline
\end{tabular}




\subsection{The poet's age when writing about Dubrovnik}

By analyzing the Table 1 it is possible to achieve the first set goal, i.e. to determine how old the poet was in each phase, assuming that in this paper the creative phase is equivalent to his age. In order to make this interpretation as clear as possible, Table 2 below presents the title of each poem and the poet's age by the time of the poem's origin respectively.

Table 2. The poet's age by the time of origin of some of the Poems of Dubrovnik

\begin{tabular}{|c|l|c|}
\hline RB & \multicolumn{1}{|c|}{ Poem's title } & Poet's age \\
\hline 1 & A thought about you & 18 yrs. \\
\hline 2 & $\begin{array}{l}\text { The old olive groves dreaming their } \\
\text { dreams }\end{array}$ & 18 yrs. \\
\hline 3 & A devotee by the blue sea & 18 yrs. \\
\hline 4 & Epistle & 46 yrs. \\
\hline 5 & My Dubrovnik & 48 yrs. \\
\hline 6 & Majesty of the sea & 49 yrs. \\
\hline 7 & Recorded in the cemetery & 54 yrs. \\
\hline 8 & To you for a birthday & 54 yrs. \\
\hline 9 & Only a wish & 54 yrs. \\
\hline 10 & Confusion & 54 yrs. \\
\hline 11 & About oblivion, about words, about wind & 56 yrs. \\
\hline 12 & $\begin{array}{l}\text { Rhymes about a dog on the cemetery } \\
\text { gate }\end{array}$ & 57 yrs. \\
\hline 13 & Servant to the words & 69 yrs. \\
\hline 14 & A poem to St. Blaise in Dubrovnik & 90 yrs. \\
\hline
\end{tabular}

The above Table 2 enables classifycation of his poetic creativity about Dubrovnik as follows:

1. Phase by the age of 20 years (A thought of you; Old olive groves dreaming their dreams; A devotee by the blue sea);

2. Phase from his 40s to the 60s (Epistle; My Dubrovnik; Majesty 
of the sea; Recorded in the cemetery; To you for a birthday; Only

a wis; Confusion; About oblivion, about words, about wind;

Rhymes about a dog on the cemetery gate);

3. Phase around the age of 70 years (Servant to the words);

4. Phase around the age of 90 years (A poem to St. Blaise in Dubrovnik).

In spite of the uninterrupted life span in which Tadijanović was inspired by Dubrovnik, it is clear that this topic occupied him in turns yet lifelong. It is clear that the poet was the most productive in his forties, fifties and sixties, but his inspiration lasted (with some interruptions) from the age of 18 to 90 , in other words for more than seventy years. This is in favor of our starting hypothesis, because the one who dedicates verses to one city during such a long time surely loves it. However, to fully prove our hypothesis, it is important to fulfill the rest of the goal. In the continuing text, it is necessary to determine which are the topics and motives the poet has approached during his four phases, as presented in theTable 2 .

\subsection{Themes and motives of the poet's four phases}

The first phase (by the age of 20 years) includes three poems whose titles are very indicative: A thought of you (subtitled: A memory on Dubrovnik), The old olive groves dreaming their dreams, and $A$ devotee by the blue sea. The poet, then 18-year-old, suggests the thoughts on his sweetheart, dream and love. We would say, nothing unusual for a boy who only until recently was a child and now enters the adult world. What is the connection to Dubrovnik?

Although none of the three poems mentioned were written in Dubrovnik, all the three are dedicated to thinking about it. In A thought about you, in his lyrical and intimate fervor the poet talks about the night atmosphere of the coast where he is sitting and talking with his friend, but regardless of the great love he feels about the sea ${ }^{1}$, the love for his "little girl" is far stronger ${ }^{2}$.

(1) Little girl, if only you knew, / How much love I feel / Towards an uneasy sea, / Large stars and the sky / In the night of deep blue. 
(Tadijanović, 2003: 7)

(2) But more than that great love / A thought on you is still stronger. (Tadijanović, 2003:7)

Although the poem Old olive groves dreaming their dreams talks about the poet's love for a girl, it was written in an idyllic intonation from which the birth of life within the natural cycle is speaking?:

(3) Green are the native vineyards. (...) // On the trees yellow lemons, / And olives, and sweet oranges, / Lavishly sending scent in the space, (...) // The wind swings slender cypresses / And the shrubs of rosy rosettes / And the green branch, blossomed. (Tadijanović, 2003: 9)

The last poem justifies its title so that the A devotee by the blue sea is a poet himself, but now the sea is a witness to his longing, sorrow, and loneliness as he longs for his beloved Sulamka $\mathrm{a}^{4}$. Similar to the first poem, he correlates the sea that he loves so much with his love for her and would give everything just to see it $^{5}$.

(4) I stand alone by the blue sea; / I look sadly in the deep sea / And for you I long, oh, Sulamka/ My darling girl far away. (Tadijanovic, 2003: 11)

(5) The bright sun burns from high above: / And the sea I would give for the two eyes / Your black and deep eyes, / My darling girl Sulamka. (Tadijanović, 2003: 11)

It is evident that love in all its forms is the fundamental theme of Tadijanović's first phase: for the nature and for the beloved girl, whose name we find out in $A$ devotee by the blue sea, and the theme is accompanied by the motives of the poet's darling, sea, vineyards, lemons, oranges and other gifts of nature. Accordant to a young man in which the first love thrills bud, he also notices the life budding in the nature. His outer landscape is in harmony with the interior one.

After a 20-year break, a 20-years long second phase (from his $40 \mathrm{~s}$ to the 60s) followed. It is a result of the poet's life experience, so verses are less dynamic, there is less of exhilaration and more of contemplations and philosophical preoccupations. 
Epistle is somewhat different, the poet addressing his beloved. The poet has never betrayed the autobiographical background of his poems, so we can be sure that he is addressing his wife Jelica Ljevaković, who is currently in Dubrovnik ${ }^{6}$. Although the poem is dominated by the expectation of her return, Dubrovnik appears elliptically at the very end of the poem ${ }^{7}$, marking the beginning and the end, and it is possible to get the impression of the hugs where the appearances of Dubrovnik as the alpha and omega represent the hands, and the central part (love for his wife) is the object of hugging.

(6) I greet you, my heart, / In a distant city; I greet you / In the eternal city, in Dubrovnik. (Tadijanović, 2003: 13)

(7) One has to / wait, still wait a bit, / Until my divine heart / Returns from the distant city. / There is still a bit to wait. (Tadijanović, 2003: 13)

The poem My Dubrovnik definitely represents a move away from Tadijanovićs poetry because he names a place, besides Rastušje, as his place. It is a worthwhile proof of his relationship to the "City of Poets" as he calls it in the same poem. In the subtitle there is a time span between 1923 and 1953, a thirty-years memory of those beautiful moments. Namely, the poem represents a kind of memory of the moment when he first went to this city. In the first three verses, we meet a nearly 18 -year-old boy ${ }^{8}$ whose love was responded by a girl ${ }^{9}$. However, there is a sudden turnaround in the last verse, Dubrovnik becoming a place of encounter of a joyful past and a tragic present, from which it is evident that she is now dead ${ }^{10}$.

(8) It was a scented May, and I / Not even eighteen / When I first arrived incame to the City / of poets. But I had a heart // In love and full of unwritten poems. Swifts were tweeting in me / and oranges blossoming. (Tadijanović, 2003: 15)

(9) I would not admit even to myself / That there was a girl in town / Who said to me: Darling, I love you. (Tadijanović, 2003: 15)

(10) In the dark room, in front of me today / There is a winter rose and cypress twig / Which I picked on a grave unknown, / On Mihajlo ... The dead bell. Silence. (Tadijanović, 2003: 15) 
The apotheosis of the sea is visible from the poem Majesty of the Sea. Although the body of the poem does not mention the word "Dubrovnik", the place of the poem's origin can be interpreted as its integral part. Besides, the poet interpolates the church on Danče and Triptihon by Nikola Božidarevićn ${ }^{11}$ where we may notice intersemiotic subtext because the citation relationship is established on the relation between the literature and other art type (Oraić Tolić 1990: 21). The poet incorporates it into the body of his poem, to preserve and further confirm Božidarević's artistic value ${ }^{[2]}$, but also to show that it is the sea which is constant and eternal, and we are only passers, mortals ${ }^{12}$.

(11) (MCCCCCXVII MENSIS FEBRVARII / NICOLAVS RHAGVSINVS PINGEBAT) (Tadijanović, 2003: 17)

(12) (...) In ancient time, he also listened to the sea-murmoring (...) (Tadijanović, 2003: 17)

The theme of transience is dominant also in the poem Recorded in the cemetery where the "cemetery "itself is an allude to transience. This poem originates form Lapad, but the cemetery on Mihajlo, mentioned in the footage, leads to a direct link to Dubrovnik. Tadijanović, in a little of Gundulić manner, shows the equality of all men in front of a death that can not be escaped. The late Ivo Vojnović, who became famous while living, his glory being materialized by others in golden script of his name on the tombstone, opposes the death of a boy who had died of a bomb blast in World War II. Aware of the transience of life, at the end of the poem he asks himself who of those who visit the tomb of their beloved is the next in the death row (13).

(13) I thoughtnk, for a moment: / Of us three alive on this cemetery now, / Who will be the first dead, skeleton, earth? / The other one will bring the roses, / Leandar, the iris, the rosemary, the broom, to leave them / At the beloved grave. And then to leave, / Alive among the living, to hate, to love. (Tadijanović, 2003: 19)

The next poem for To you for a birthday is also based on the contrasting relationship between the past and present, and a fear of the

[2] Prosperov Novak in his history of literature points out that this poem is "a kind of praise for renaissance painter Nikola Bozidarević" (Prosperov Novak, 2003: 357) 
future. One feels the poet's sorrow for the days when he was young and enthusiastic ${ }^{14}$ and, in the context of the content framework of the entire collection, it can be assumed that he is suffering because of the current state of "darkness, suffering, grief" (Tadijanović, 2003: 21). Although Dubrovnik is not mentioned in any verse, it is an integral part of the poem and its place of origin - Dubrovnik, or more specifically: Park Gradac. Thus, this city becomes a place of reflection on the present, or a place of wish to return to the past.

(14) And I Want / To shout loudly in shrillness of / My darkness, my pain, my grief, / To sing to the sky as in the days / Of green: (...) (Tadijanović, 2003: 21)

In the same tone there continues Only a wish, but in addition to transience, here again we have an illusion of memory (false or real), a memory of a girl who offers forgiveness and comfort to the poet ${ }^{15}$.

(15) The girl herself / Will say: Get off, rest here; In my lap you will forget everything, I In my lap you will discover offspring. (Tadijanović, 2003: 23)

Drab and gloom spill over in the Confusion, its short verses being short like life. The poem originating from Dubrovnik is somewhat rebellious about the past but also the future years of life. It seems that the poet still has so much unlived ahead and can not be reconciled with the fact that all things will come to an end ${ }^{16}$.

(16) Years were measured, poured / To the edge, as a glass. Start / Confession, a heart forgotten. (...) / Cry out! Rush among the mystery of grass, / In the mountains, under the ruins; (...) (Tadijanović, 2003: 25)

About oblivion, about words, about wind links the past, present and future, playing with time categories. In the poem, he evokes the people who have left their mark on future generations ${ }^{17}$ and fears of what will happen in the future.

(17) If I was to address the shadow of the progenitors, / Arthur, Guillaume, Tin, I would say: Please take me under the arm, take 
me / Among the blue oakes to oblivion of the world, / Into the gurgle of blood, into the dream of righteous. (...) (Tadijanović, 2003: 27)

In the last poem of the second stage, in the Rhymes about a dog on the cemetery gate, the motive of the cemetery is also present, and so the transience. After an unsuccessful stay at the hospital, the poet goes to the Boninovo cemetery to visit the grave of Josip Kosor. However, he is hindered by a dangerous sheffer, tied to the gate, but without a muzzle ${ }^{18}$. Because of the later misunderstanding, the poet accidentally offends an innocent old woman for which he regretted ${ }^{19}$.

(18) (...) I yelled: "Damned dog, and let be damned / A stupid master who leaves you there. (Tadijanović, 2003: 29)

(19) (...) Oh, let me never repeat it to anyone, not in a dream / Not in a reality, and let no dog ever wait for me / At the cemetery gate; let rather a death waith for me (...) (Tadijanović, 2003: 31)

The common of all these poems of the second phase is a very dark, depressing and gloomy tone. The poet is aware the death approaching day by day and can not and will not reconcile with it. The basic theme is the transience of life, interwined with the once beloved girl who died at the time of his visit to Dubrovnik, cemetery being his frequent motive.

There was only one poem in the third phase (70s) - Servant to the words. It is a resume of his poetic creativity, where he interpolates himself in the title of the poem with a syntagm expressing his relation to the words, or the relation of the words to him ${ }^{20}$. Reviewing the past seems to be his slow remission from the earthly, not because he would like to, but because he thinks his time is come.

(20) and the sea and the flowers and the mouth / were telling him / you have your whole life been / a servent to the words and they / were a penitentionary and source / of sadness and joy / in your poems (...) (Tadijanović, 2003: 33)

The fourth phase (90s) is marked by A poem to St. Blaise in Dubrovnik, imagined as a direct addressing to the Dubrovnik saint. The importance of Dubrovnik is again highlighted in this poem, again 
being written with a capital $\mathrm{G}$ for Grad (the City) ${ }^{21}$ and asking to bless the Croatian renaissance poets Šiško Menčetić and Džora (Đor) Držić.

(21) The number is unknown, of how many times I've comel To your city, and mine, to watch every day, / How you carry it on your holy palm. // You know well that many poems / I have written here, in the shadow of your city, / But I never mentioned you. (Tadijanović, 2003: 35)

At the very end of this subsection, it should be noted that the connection between all these phases is in remembering and in memory, because every space, and in this case also the space of Dubrovnik, is indelible. This is why Bachelard argues that "topoanalysis should be a systematic psychological study of the sites of our intimate lives (Bachelard, 2000: 31). This may be recognized in the interpretation and analysis of the results of our research whereby Dubrovnik is exposed as Tadijanovićs intimate space ${ }^{[3]}$.

In this sense, Nemec's importance is in recognizing a moment in which "the city loses its physical and objective properties" (...) and now the writer who writes about the city is defined by numerous components: "events, emotions, traumas, encounters and personal relationships that coexist in time" (Nemec, 2010: 201). Thanks to his intimate experience of the city, which he re-actualizes in his rememberings and by re-experiencing of memories, it may be stated that the city functions through two codes: one is the public that the widgneral audience would observe in the same or similar way, and the other is the personal one - in this case inherent to Tadijanović alone and his private experience. At this point it is interesting to ask the question whether the poet's personal experience may partly become a part of someone else's personal experience by repeated reading of the same verses?

[3] At this point it is interesting to mention the interpretation of the editors of a book Culture of remembering, where in the introduction titled Why memories and rememberings they say that memory is still "deeply social phenomenon and we find it in the rules, laws, standardized procedures and records (...), books, holidays, statues, souvenirs " (Brkljačić and Prlenda, 2006: 13). However, we disagree with this view because the examples of Tadijanović's memory are only sometimes associated with collective memory, though it is dominated by the individual. 


\section{Conclusion}

Before the research we had set the hypothesis that the poet loved to stay in Dubrovnik, although literature historians often accentuated that he preferred village over the town(s). With the goals set, we have proved it to be true, thinking that his intolerance and loneliness in the city is merely a product of inadequate life experience and stress due to the sudden change (leaving the village to the schooling in town, in this case Slavonski Brod, which is a common fact).

It is important to point out that the poet is inspired by Dubrovnik as very young, in the first phase, as an 18-year-old, but there is no unease because of his stay in the city. However, in moments when he is lonely and desires his beloved, the poet does not assign the sumptuous epithets to Dubrovnik. To him, it is always eternal and special, just like the eternal memories he is experiencing again, especially in the case of former beloved ones.

The poet's later life, in the second phase, certainly influenced the change of the theme and motives of his poems, so Dubrovnik turned into a place of reflection on the transience of life that contrasts with the relationship of life and death and becomes a fact by a real, autobiographical authentic image of two cemeteries visited by the poet. It is the place where he ultimately reflects on his life, which will be deepened in the later, third phase, giving a cross-section of his literary creativity. However, as his seventies were not the end, he will also be present in his nineties, during the fourth phase, completing the entire Dubrovnik story by addressing an all-time and universal saint. This is the way Tadijanović almost masterfully connected past, present and future, proving that Dubrovnik is not called the "eternal" for no reason. 


\section{REFERENCES}

Bachelard, Gaston. Poetika prostora. Zagreb: Ceres.

Barthes, Roland. 1989. Carstvo znakova. Zagreb: „August Cesarec“.

Brkljačić, Maja i Sandra Prlenda, „Zašto pamćenje i sjećanje“, u: Kultura pamćenja i historija, priredile Maja Brkljačić i Sandra Prlenda. Zagreb: Golden marketing - Tehnička knjiga, str. 9-18.

Frangeš, Ivo. 1987. Povijest hrvatske književnosti. Zagreb - Ljubljana: Nakladni zavod Matice hrvatske - Cankarjeva založba.

Jelčić, Dubravko. 2004. Povijest hrvatske književnosti, drugo, znatno prošireno izdanje. Zagreb: Naklada P. I. P. „Pavičić“.

Mumford, Lewis. 1968. Grad u historiji: njegov postanak, njegovo mijenjanje, njegovi izgledi. Zagreb: Naprijed.

Nemec, Krešimir. 2010. Čitanje grada: urbano iskustvo u hrvatskoj književnosti. Zagreb: Naklada Ljevak.

Oraić Tolić, Dubravka. 1990. Teorija citatnosti. Zagreb: Grafički zavod Hrvatske.

Prosperov Novak, Slobodan. 2003. Povijest hrvatske književnosti. Od baščanske ploče do danas. Zagreb: Golden marketing.

Tadijanović, Dubrovnik. 2003. Pjesni dubrovačke. Dubrovnik: Matica hrvatska. 